\title{
"Manager profile in organizations providing social services: Evidence from the Czech Republic"
}

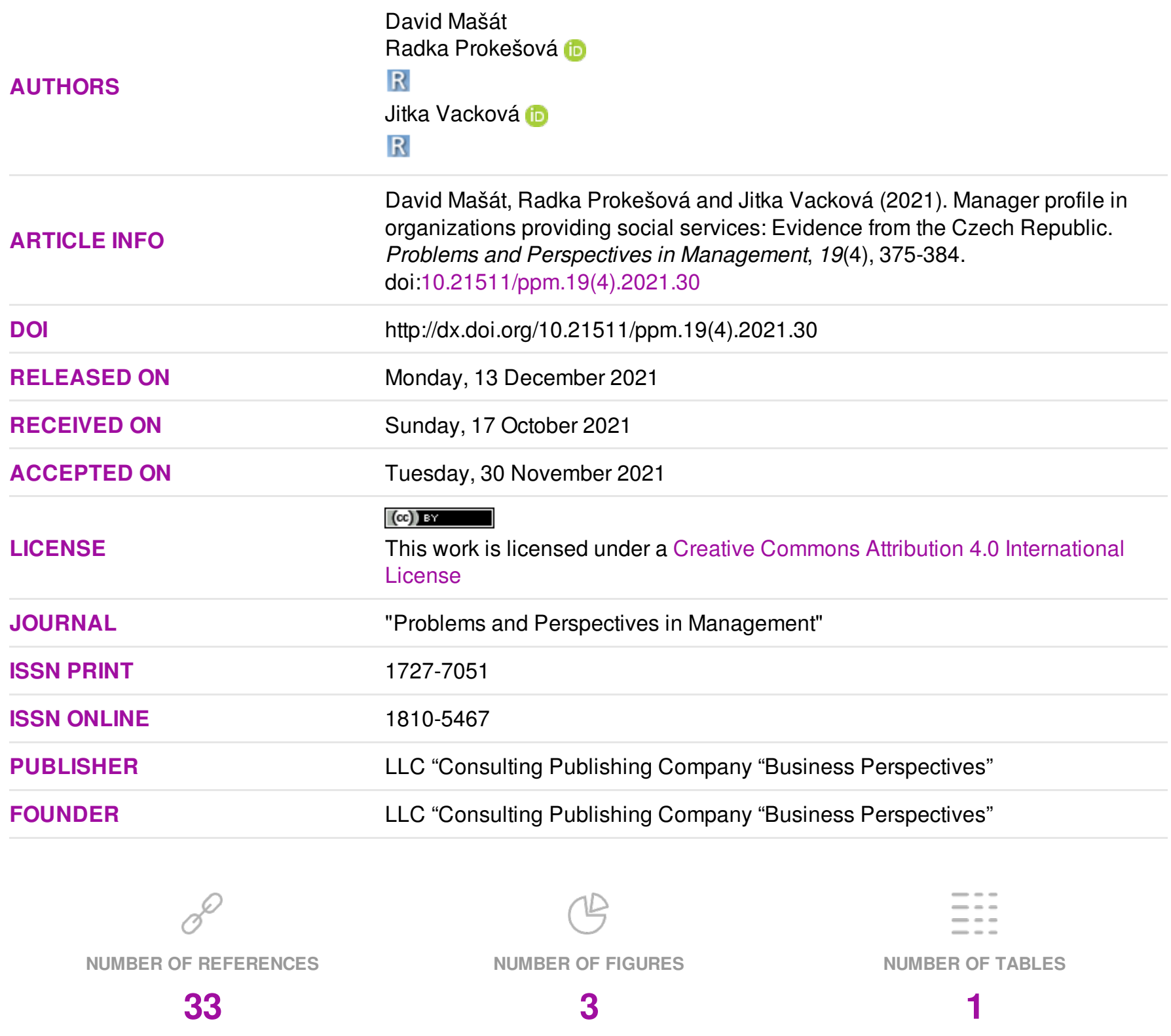

(c) The author(s) 2021. This publication is an open access article. 


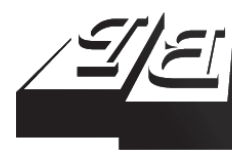

\section{BUSINESS PERSPECTIVES}

LLC "CPC "Business Perspectives" Hryhorii Skovoroda lane, 10, Sumy, 40022, Ukraine www.businessperspectives.org
Received on: $17^{\text {th }}$ of October, 2021 Accepted on: $30^{\text {th }}$ of November, 2021 Published on: $13^{\text {th }}$ of December, 2021

๑ D David Mašát, Radka Prokešová, Jitka Vacková, 2021

David Mašát, Mgr., Faculty of Health and Social Sciences, Institute of Social and Special-Educational Sciences, University of South Bohemia in České Budějovice, Czech Republic.

Radka Prokešová, Ing., Ph.D., Faculty of Health and Social Sciences, Institute of Humanities in Assisting Professions, University of South Bohemia in České Budějovice, Czech Republic. (Corresponding author)

Jitka Vacková, Ph.D., Associate Professor, Faculty of Health and Social Sciences, Institute of Social and SpecialEducational Sciences, University of South Bohemia in České Budějovice, Czech Republic.
David Mašát (Czech Republic), Radka Prokešová (Czech Republic), Jitka Vacková (Czech Republic)

\section{MANAGER PROFILE \\ IN ORGANIZATIONS PROVIDING SOCIAL SERVICES: EVIDENCE FROM THE CZECH REPUBLIC}

\begin{abstract}
A profile of manager represents characteristics of a person performing a managerial position, i.e., it includes qualities such as knowledge, skills, and competencies within a specific specialty that provides the ability to carry out managerial duties and responsibilities successfully. The reason for obtaining this information is to build a profile of managers in organizations providing social care, as this area has not been elaborated in detail in the Czech Republic.
\end{abstract}

This study aims to identify and describe the profiles of managers in organizations providing social services in the South Bohemian Region. The study was conducted using semi-structured interviews with 24 managers of selected organizations providing social services in the South Bohemian Region until the information obtained was sufficient. Data were processed using open, selective, and axial coding.

Managers were asked about their job descriptions, their skills and education, and the specifics of their duties and responsibilities within their organizations. The results show that manager profiles are influenced by the type of organization and the organization's funding. The results of the study showed that specific managerial duties and responsibilities are based on the type of social service provided. These duties and responsibilities are also based on the clients of services and the frequency of services provided.

\section{Keywords}

social work management, social services organizations, manager, knowledge, skills, competencies

\section{JEL Classification $\quad$ M12, M19}

\section{INTRODUCTION}

Compared to other disciplines, a manager profile has not been sufficiently described in sociological works yet. Since 1989, organizations providing social services in the Czech Republic have been undergoing extensive development, which has undoubtedly affected the management of these organizations. Social work is considered particularly important because it closely follows its mission to promote human well-being and help meet the basic needs of all people (Colnar et al., 2019). The managerial concept in these organizations is based on current development in social policy, in which the state plays a strategic role. Social work management is a key component of the overall management of social services.

A manager in social services is a person whose main task is to lead and manage a company or an organization so that it meets the set goals and achieves the desired results; in addition, he/she must lead the individual components of the company to function as a whole (Folwarczná, 2010). At the same time, this person is responsible for the work of others who are authorized; it is the manager who directs and leads the staff. Currently, this concept is defined primarily as a profession, and 
its holder is responsible for achieving goals using a team of co-workers and resources provided, including creative participation, setting goals, and securing them, as this employee by appointment, assignment, delegation, or election actively implements management activities for which person is equipped with the appropriate competencies (Lednický, 2008).

\section{LITERATURE REVIEW}

Social services are provided to socially disadvantaged people to improve their lives (Matoušek, 2012). Social services do so by assisting with personal care, meals, accommodation, assistance in running a household, nursing, education assistance, providing information, mediation of contact with the social environment, psychotherapy and sociotherapy, assistance with the assertion of rights and interests (Duková et al., 2013).

Act No. 108/2006 Coll. on Social Services defines the basic types of social services as social counseling, social welfare services, and social prevention services.

Social counseling includes basic social counseling and professional social counseling (Arnoldová, 2016). Basic social counseling provides people with the necessary information to help resolve their unfavorable social situation, while professional social counseling focuses directly on individual social groups' needs (Arnoldová, 2016).

Social welfare services help people with physical and psychological self-sufficiency (Králová \& Rážová, 2012). It promotes life within natural social environments and encourages, as much as possible, full participation in the daily life of society (Králová \& Rážová, 2012). If their condition prevents this, the goal is to provide them with treatment and a dignified environment (Králová \& Rážová, 2012).

Social prevention services help prevent social exclusion of persons at risk because of a crisis social situation, life habits, and lifestyle leading to conflict with society, a socially disadvantaged environment, and a threat to the rights and legitimate interests of another person's criminal activity (Matoušek, 2011).

According to Schneiderová (2010), social service managers in the Czech Republic differ from usu- al business managers as in business, social service is a secondary objective, whereas in organizations providing social services, the social value is the main objective.

Social service managers face high staff turnover and a lack of qualified staff; therefore, they must devote efforts to training and recruiting staff to minimize the turnover in their organizations (Hayes \& Ninemeier, 2009). Leadership has become an essential quality of social work management. The role of this quality in social work as a profession is still evolving (Zhang et al., 2020). The competencies, skills, and knowledge of managers are reflected in their duties and responsibilities $(D / R)$ and can affect the direction and success of the whole organization (Mikova et al., 2019). The role of a social service executive is to guide managers in a way that mobilizes their skills and uses their strengths effectively (Schneiderová, 2010).

A manager profile includes their personality, which is characterized by a certain charisma and strength of personality, the power of informal authority, and the ability to understand people and respond to them; it also includes motivation and leading by example, which is important since managers directly influence the actions of people in relation to performance and quality work, influence the work atmosphere, and play a role in promoting employee development (Mikuláštík, 2015). Blažek (2014) also emphasizes the importance of a manager's personality, stating that managers are expected to bring ethical commitments, social justice values, consideration of the client's interests, understanding human behavior, and interpersonal skills to their position.

Social service managers are subject to the same demands as senior managers in large corporations (Šedivý \& Medlíková, 2017). Social service managers, like managers in the business sector, have a greater degree of responsibility for the day-today operations of an organization and implement their objectives through subordinate employees 
Table 1. Research set for qualitative data analysis - Directors of organizations

\begin{tabular}{|c|c|c|c|c|c|c|c|c|c|c|c|}
\hline \multirow[b]{2}{*}{ Directors } & \multicolumn{2}{|c|}{ Gender } & \multicolumn{3}{|c|}{ Age } & \multicolumn{6}{|c|}{ Length of employment } \\
\hline & male & female & $\begin{array}{l}\text { up to } 35 \\
\text { years }\end{array}$ & $\begin{array}{l}36-50 \\
\text { years }\end{array}$ & $\begin{array}{l}51 \text { years } \\
\text { and over }\end{array}$ & $\begin{array}{l}\text { Up to } 1 \\
\text { year }\end{array}$ & $\begin{array}{c}2-3 \\
\text { years }\end{array}$ & $\begin{array}{c}4-5 \\
\text { years }\end{array}$ & $\begin{array}{c}6-9 \\
\text { years }\end{array}$ & $\begin{array}{l}10-13 \\
\text { years }\end{array}$ & $\begin{array}{l}14 \text { years } \\
\text { or more }\end{array}$ \\
\hline Frequency & 7 & 17 & 0 & 13 & 11 & 1 & 2 & 2 & 4 & 4 & 11 \\
\hline Percentages & $29.2 \%$ & $70.8 \%$ & $0 \%$ & $54.2 \%$ & $45.8 \%$ & $4.2 \%$ & $8.3 \%$ & $8.3 \%$ & $16.7 \%$ & $16.7 \%$ & $45.8 \%$ \\
\hline Overall & \multicolumn{2}{|c|}{24} & \multicolumn{3}{|c|}{24} & \multicolumn{6}{|c|}{24} \\
\hline
\end{tabular}

Note: Data were processed in ATLAS.ti using open, selective, and axial coding.

or volunteers (Matoušek, 2013). Knowledge, experience, ability to learn, effective communication, understanding the functioning of the market and competition - all these are important for the healthy development of an organization providing social services (Šedivý \& Medlíková, 2017). Folwarczná (2010) further elaborates the characteristics of a manager as someone whose main task is to lead and manage an organization to meet goals that have been set and achieve the desired results; in addition, a manager must manage individual components of an organization so that they function as a whole. Managers must also understand social issues, the economy, and management methods. They must communicate effectively and be in good mental and physical condition (Doležal, 2016). According to Provazník et al. (2012), managerial skills are closely related to education and experience. Task and interpersonal skills also play an essential role in managerial competence (Bedrnová et al., 2015).

Based on these findings, the main aim of the study is to identify and qualitatively profile managers working for organizations providing social services in the South Bohemian Region.

\section{METHODOLOGY AND CHARACTERISTICS}

The research topic "manager profile in organizations providing social services" is related to the project "Selected Aspects of Social Work Management", registration number GAJU 052/2019/S (Grant Agency of the University of South Bohemia in České Budějovice).

The study was carried out using a qualitative research strategy between August 2019 and March 2020 using semi-structured interviews with 24 managers of South Bohemian social service or- ganizations. Respondents were selected from all organizations that provide social services in the territory of the South Bohemian Region (i.e., all organizations in the register of social service providers were included). The criterion for selecting respondents was a company size according to the number of registered services (according to the Register of Social Service Providers), a type of organization, and types of social services provided (again, according to the Register of Soc. Service Providers). Managers were asked about their competencies, skills, education, personal characteristics, and their role in social work. They were also asked about the specifics of the $\mathrm{D} / \mathrm{R}$ of managers in social services with regard to a type of organization. Twenty-four completed interviews were collected. The average duration of the interview was one hour.

The structure of the research group concerning gender, age, and length of employment is shown in Table 1.

The study was approved by the Ethics Committee of the Faculty of Health and Social Sciences of JU. All personal data were processed following the Regulation 2016/679 of the European Parliament and the EU Council as of April 27, 2016, regarding the protection of individuals with regard to the processing of personal data and the free movement of such data and the repeal of Directive 95/46/EC. Anonymity was ensured during data collection; respondents were not exposed to any personal or professional risks associated with their participation in this study.

\section{RESULTS}

The results contain job descriptions, managerial skills, and the specific $D / R$ of managers working for social service organizations in the South 


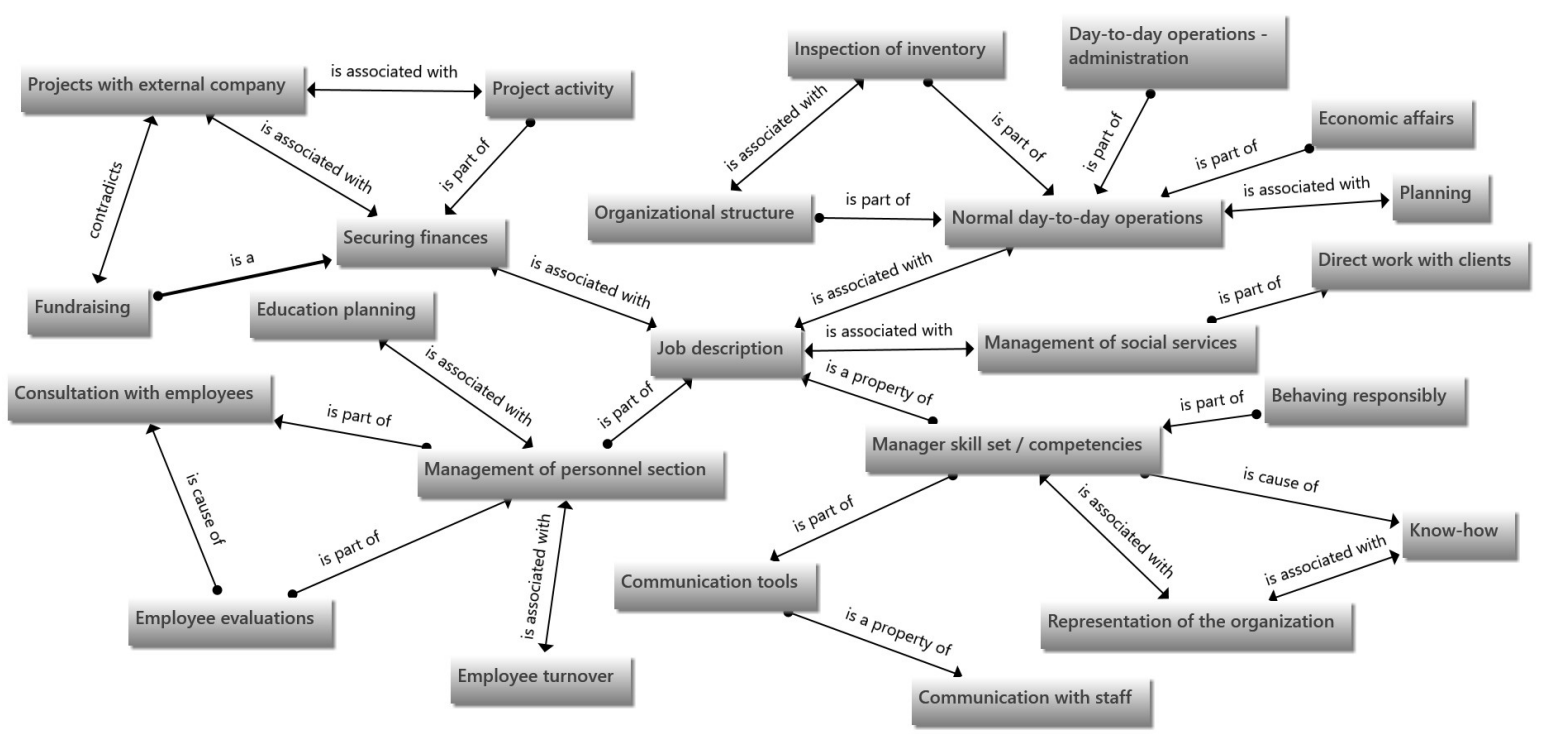

Figure 1. Job description of managers working for social services organizations in the South Bohemian Region

Bohemian Region, CZ. The reason for obtaining this information from respondents was to form a profile of managers in social service organizations.

\subsection{Job description}

Social service managers were asked about their work $\mathrm{D} \backslash \mathrm{R}$. This information is shown in Figure 1.

Ten directors reported $\mathrm{D} / \mathrm{R}$ that included fundraising; only two organizations used an external company for fundraising. Two other directors also reported fundraising as their job responsibility.

Eleven managers reported that managing the HR department was one of their D/Rs, including scheduling staff training, employee meetings, and staff evaluations. HR management also includes managing staff turnover (i.e., staff may depart due to a manager's dissatisfaction with employee performance, or employees may depart because they are dissatisfied with an organization or its management).

An essential part of the job of a social service manager is finding solutions to various troublesome situations, which six managers described as problems within their organization or with clients or employees. Most managers included communication, both internally with employees and externally in the form of $\mathrm{PR}$, or representation of the organization as a $\mathrm{D} / \mathrm{R}$. According to three man- agers, their know-how was crucial for effective external communication. Six managers included the management of social services in their $D / R$, while eight managers included direct work with clients in their $\mathrm{D} / \mathrm{R}$.

The most commonly mentioned $\mathrm{D} / \mathrm{R}$ was administration, which all managers reported. This included economic issues, work planning, and equipment inspection. Ten managers analyzed their role in the day-to-day running of an organization. Nine directors mentioned supervisory responsibilities in their responses.

There were several notable items related to different managerial duties in different types of organizations. For example, several managers reported that they were solely responsible for finding innovative solutions to difficult situations.

A significant difference was observed concerning the financing of an organization. Organizations set up by a city or region were found to have much fewer funding problems than non-governmental, nonprofit organizations, which are largely dependent on subsidies and grant from cities, regions, ministries, or the European Union.

Another interesting fact emerging from the analysis is that some organizations operate using volunteers and therefore have lower operating costs. 


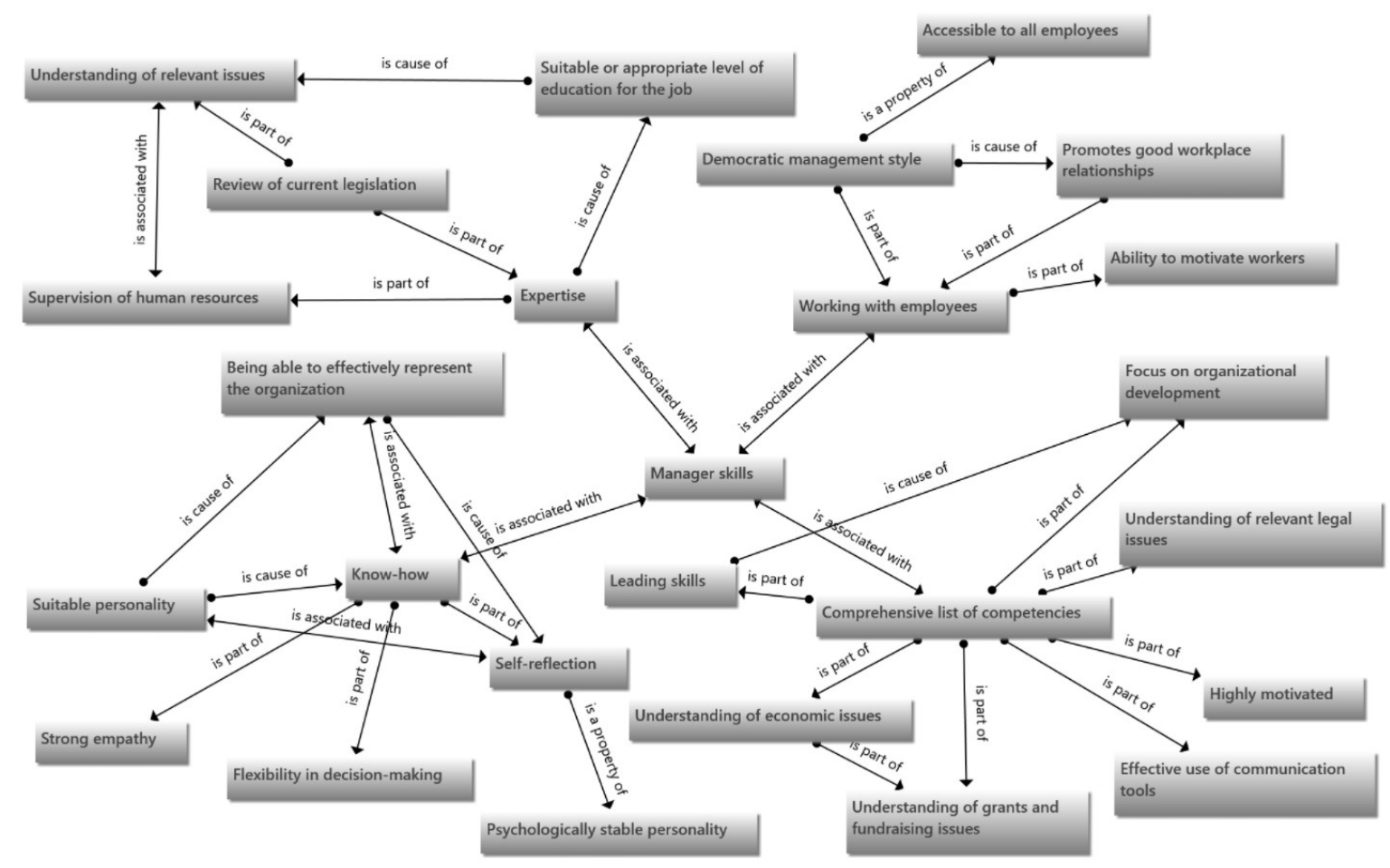

Figure 2. Skillset of social service managers in the South Bohemian Region

\subsection{Manager skills}

Figure 2 shows what skills a manager should have in an organization providing social services based on manager interviews.

Among the skills, directors included expertise, especially in finance issues, human resources, and current legislation. The findings show that these skills are also related to education.

Within their skills, managers often cite their know-how, which can be interpreted in different ways. Some understand it as the use of practical thinking in management, while four managers described it as flexibility in decision-making. Four other managers claimed that knowhow influences a manager's personality. Strong empathy was also associated with personality, which can significantly influence attitudes and behavior. A manager's personality is related to their ability to promote their organization properly. Managers also mention self-reflection as a significant part of their know-how.

According to nine managers, management skills essential for a functioning organization are the most represented ones in the comprehensive list of competencies. Twelve managers also included an understanding of economics, and eight managers included an understanding of funding and grants. Eleven respondents listed an understanding of legal issues as being critically important skills. Eight managers describe being highly motivated, and 15 managers describe the need to be effective communicators.

Four managers described working with employees and motivating them to perform better as part of their job description. Creating good relationships in the workplace is an integral part of working with employees, which according to five managers, is associated with a democratic management style characterized by equal access. An interesting fact about this result is that managers talk about a democratic management style, although only they, as managers, are likely to have and exercise authority within an organization. In a significant number of responses, it was noted that when asked about their thoughts on the ideal manager skillset, the interviewees answered with their own skillsets, as though they felt that they were an excellent example of an ideal manager. 


\subsection{Specifics of duties and responsibilities of individual managers}

The specific $D \backslash R$ for individual social services managers in the South Bohemian Region is shown in Figure 3.

Regarding the specific skills of their profession in the organization, four directors reported that seeking new opportunities and options was vital since it significantly affects the organization's effectiveness.

Six managers included social service offering in their $\mathrm{D} / \mathrm{R}$, as it is related to specific social services provided by their organization. Six directors included client assistance, and three managers included supervision on the quality of provided services.

Four managers included specific funding for social services, which included funds from city budgets, and also indicated that some services were free for clients.

Seven managers listed $\mathrm{D} / \mathrm{R}$ that varied depending on the type of social service provided.

Interestingly, eleven managers stated that they had similar overall goals and objectives as other social services.
The last item concerns the frequency of contact with clients of an organization. Some managers reported that they had to actively seek clients who needed services or wait for clients, while other managers reported that their organization had a large clientele and actively seeking out clients in need of services was unnecessary.

\section{DISCUSSION}

This study provided information on job descriptions, managerial skills, and the specifics of managerial $\mathrm{D} \backslash \mathrm{R}$ provided by social services managers in the South Bohemian Region.

The job of a manager in social services organizations can be divided into five subgroups, which are (1) financial, (2) management of the personnel department, (3) having a broad skillset, (4) providing social services, and (5) day-to-day operations. The job of a manager in social services includes securing finance for their projects as well as fundraising. Hejduková et al. (2018) commented on the financing of the nonprofit sector; as a manager, securing financing is critical to finance daily operations, maintain business relationships, and fulfill organizational objectives.

Management of the personnel department includes training planning, consultation with em-

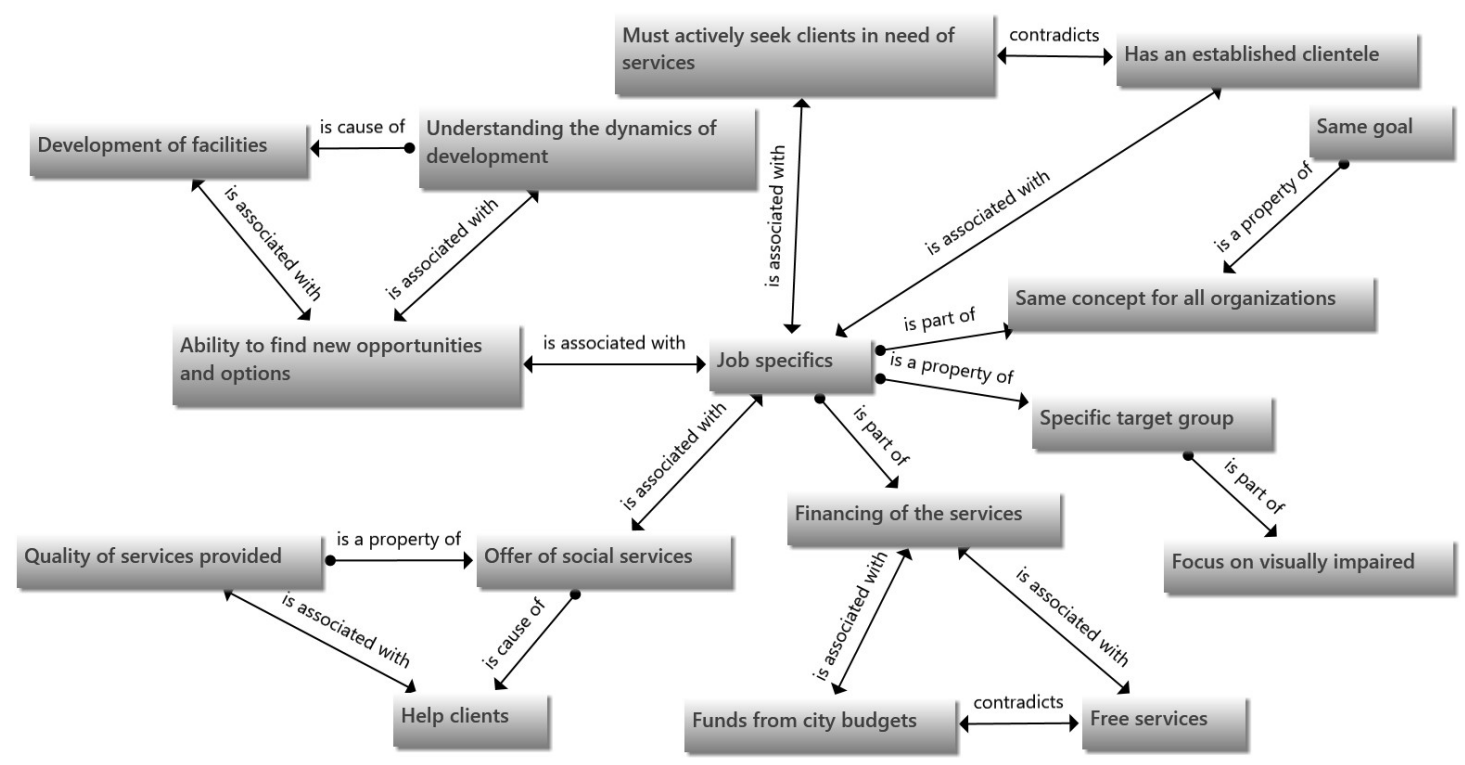

Figure 3. Specifics of duties and responsibilities for individual social services managers in the South Bohemian Region 
ployees, evaluation of employees, selection of reliable staff, and managing employee turnover. Masopust (2019) partially agrees with respondents that managers are responsible not only for themselves, but also for their subordinates, whom they must evaluate, task, delegate, sanction, and reward. The study has shown that an essential part of a manager's job is having a broad set of competencies, which includes know-how, representation of an organization, use of communication tools, and communication with staff. Matoušek (2013) also mentions communication as part of the social service manager's $D \backslash R$ and says that it is very important to be able to communicate with different types of clients, colleagues, and the public. The managerial job description also includes the provision of social services and related activities, direct work with clients, and ensuring the quality of provided services.

Schneiderová (2010) confirms the thesis that social services managers often participate in the direct provision of social services to clients. Managerial duties also include economic planning, administration, and supervision. Under the views of the respondents, Fotr et al. (2020) include planning, human resources management, administration, and supervision as managerial $\mathrm{D} \backslash \mathrm{R}$. In this context, the education of these managers is critical. That managers in social services generally have more education in economics, social work nursing, and other non-medical fields. This corresponds to the fact that until recently, there were no educational programs specifically for social service managers in the Czech Republic.

Results show that the most important managerial skills for managers in social service organizations are those related to expertise, know-how, a broad skill set, and the ability to work with employees. Mangers also mentioned familiarity with important issues, management of human resources, familiarity with current legislation, and education.

Lojda (2011) emphasizes skills of a technical nature, such as the application of managerial techniques in addition to the above-mentioned expertise. Know-how skills are related to the representation of an organization, the manager's personality, having empathy, the flexibility of decision-making, as well as self-reflection. Lojda (2011) agrees with the results regarding basic managerial skills such as understanding their limitations, critical thinking, and self-reflection, and self-management. Managerial skills also include an understanding of economic issues, understanding grant processes, being motivational, effective use of communication tools, an understanding of legal matters, and an understanding of development and management skills.

Korecký and Trkovský (2011) have similar views and describe managerial skills to include intervention planning, communication, decision-making, prioritizing innovations in management, project and service supervision, and evaluation. Lojda (2011) also agrees with these skills and adds skills such as human resources management, leadership, motivation of employees, delegation of authority, and negotiation skills. Khelerová (2010) agrees with the results of this study; when she describes skills as practical habits that can be acquired through practice, it is mainly about work organization and time management, people management and motivation, delegation, communication skills, and working with PCs. Future trends of effective management include the development of collective leadership and the application of technological literacy (Megheirkouni, 2018).

Marková (2018) showed that the predominant leadership style in selected organizations providing social services is leadership based, whereas Tham and Strömberg (2020) found that organizations emphasize ideals and prioritize the provision of support and advice subordinate social workers and push managers into leadership roles characterized by supervision and authority, where they use quantitative measurements to monitor and supervise operations. Tafvelin et al. (2018) identified factors that hinder managerial performance at the organizational level, such as top-down management, financial burdens, and constant change, as well as at the local level such as lack of support, heavy workloads, limited influence, administrative tasks, and remoteness from employees.

Regarding the specifics of managerial duties and responsibilities for social service organizations, it was not possible to demonstrate significant differences relative to the type of an organization; however, there were variations in managerial work- 
load between types of organizations. For example, several managers reported that they were alone in an organization when it came to finding innovative solutions to problems. Mátel (2019) noted that social work is currently a rapidly evolving scientific discipline that is full of innovations both in theory and practice.

According to Clarkson et al. (2020), charismatic and transformative leadership is critical for stimulating positive changes within organizations. It was noted that organizational funding methods affected managerial duties and responsibilities. Organizations set up by cities or regions were found to have far fewer fund- ing concerns than non-governmental, nonprofit organizations, which depend heavily on grants and funding from cities, regions, ministries, or the European Union. Špalek et al. (2017) reported similar findings. Several managers reported that organizations differed in the range of specific social services provided, for example, services directed toward people with autism, visual impairments, or victims of crime. Another interesting fact was that some organizations operate using volunteers and therefore have lower operating costs. Vojtíšek (2018) agrees, noting that the use of volunteers can reduce costs compared to other social service providers using paid employees.

\section{CONCLUSION}

The aim of this study was to identify and qualitatively profile managers working for organizations providing social services.

The study of manager profiles contains information on job descriptions, manager skills, and specific duties and responsibilities of these managers. As part of their job description, managers cited project and fundraising activities, personnel management, and public relations. Managers also described administrative duties, including financial planning, supervision, and development of organizational structures.

The study showed that among the most important skills of managers in this area is the ability to direct their organization's development, as well as the understanding of economic issues, understanding of grant processes, understanding of relevant legal issues, the ability to motivate subordinates, and the ability to communicate.

Specific managerial duties and responsibilities are based on the type of social service provided, the clients of services, and the frequency of services provided. The managers also mentioned innovations in education and seeking new ways to positively influence the development of their organization.

The study, which reflects the experience of the interviewed managers, can be used not only to create a profile of these managers but also to generate recommendations for improvement through examples of good practice noted in the study. These results can be used to design managerial training to cover weaknesses in social services organizational management, particularly as it relates to financing different types of organizations.

\section{AUTHOR CONTRIBUTIONS}

Conceptualization: David Mašát, Radka Prokešová, Jitka Vacková.

Data curation: David Mašát.

Formal analysis: David Mašát, Radka Prokešová, Jitka Vacková.

Investigation: David Mašát.

Methodology: David Mašát, Radka Prokešová, Jitka Vacková.

Project administration: Radka Prokešová, Jitka Vacková.

Resources: David Mašát. 
Software: David Mašát.

Validation: David Mašát, Radka Prokešová, Jitka Vacková.

Visualization: David Mašát.

Writing - original draft: David Mašát, Radka Prokešová, Jitka Vacková.

Writing - review \& editing: David Mašát, Radka Prokešová, Jitka Vacková.

\section{ACKNOWLEDGMENT}

This study was financially supported by the project "Selected aspects of social work management", registration number GAJU 052/2019/S (Grant Agency of the University of South Bohemia in České Budějovice).

\section{REFERENCES}

1. Arnoldová, A. (2016). Sociální péče 2. díl, učebnice pro obor sociální činnost [Social care. Part 2, textbook for the field of social activity] ( ${ }^{\text {st }}$ ed.). Prague: Grada. (In Czech).

2. Bedrnová, E., Jarošová, E., Nový, I., Cipro, M., Kašparová, E., Králová, T., Lorencová, H., Lukeš, M., Pauknerová, D., \& Surynek, A. (2015). Manažerská psychologie a sociologie [Managerial psychology and sociology]. Prague: Management Press. (In Czech).

3. Blažek, L. (2014). Management: organizování, rozhodování, ovlivňování [Management: organizing, decision-making, influencing] ( $2^{\text {nd }}$ ed.). Expert (Grada). (In Czech).

4. Clarkson, B. G., Wagstaff, C. R. D., Arthur, C. A., \& Thelwell, R. C. (2020). Leadership and the contagion of affective phenomena: A systematic review and mini meta-analysis. European Journal of Social Psychology, 50(1), 61-80. https://doi.org/10.1002/ejsp.2615

5. Colnar, S., Dimovski, V., \& Bogataj, D. (2019). Knowledge management and the sustainable development of social work. Sustainability, 11(22), 6374. https:// doi.org/10.3390/su11226374

6. Doležal, J. (2016). Projektový management: komplexně, prakticky a podle světových standardi̊ [Project management: comprehensively, practically and according to world standards]. Prague: Grada. (In Czech).
7. Duková, I., Duka, M., \& Kohoutová, I. (2013). Sociální politika, učebnice pro obor sociální činnost (1 $1^{\text {st }}$ ed.). Praha: Grada. (In Czech).

8. Folwarczná, I. (2010). Rozvoj a vzdělávání manažerů [Development and education of managers] ( $1^{\text {st }}$ ed.). Prague: Grada. (In Czech).

9. Fotr, J., Vacík, E., Souček, I., Starling, M., \& Hájek, S. (2020). Tvorba strategie a strategické plánování: teorie a praxe [Strategy development and strategic planning: theory and practice] ( $2^{\text {nd }}$ ed.) Prague: Grada. (In Czech).

10. Hayes, D. K., \& Ninemeier, J. D. (2009). Human resources management in the hospitality industry. John Wiley \& Sons.

11. Hejduková, P., Hommerová, D., \& Krechovská, M. (2018). Řizení neziskových organizací: kličové oblasti pro jejich udržitelnost [Management of nonprofit organizations: key areas for their sustainability] ( $1^{\text {st }}$ ed.). Prague: Grada. (In Czech).

12. Khelerová, V. (2010). Komunikačni a obchodní dovednosti manažera [Communication and business skills of the manager] ( $3^{\text {rd }} \mathrm{ed}$.). Prague: Grada. (In Czech).

13. Korecký, M., \& Trkovský, V. (2011). Management rizik projektü: se zaměrením na projekty $v$ průmyslových podnicích [Project risk management: focusing on projects in industrial enterprises]. Prague: Grada. (In Czech).
14. Králová, J., \& Rážová, E. (2012). Sociálni služby a príspěvek na péči [Social services and care allowance] ( $4^{\text {th }}$ ed.). Olomouc: Anag. (In Czech).

15. Lednický, V. (2008). Stručná učebnice základů management $\left(2^{\text {nd }}\right.$ ed.). Ostrava: Repronis Ostrava. (In Czech).

16. Lojda, J. (2011). Manažerské dovednosti [Managerial skills] ( $1^{\text {st }}$ ed.). Prague: Grada. (In Czech).

17. Marková, A. (2018). Leadership in social care: A case study from the Czech Republic. European Conference on Management, Leadership \& Governance. Kidmore End. Retrieved from https://www.proquest.com/openview/729869145d 1ae503b3d08133f75ad6dc/1?pqorigsite $=$ gscholar $\& \mathrm{cbl}=1796418$

18. Masopust, T. (2019). Sociální pracovník jako manažer [Social worker as a manager]. Social services, 11(8-9), 27-28. Retrieved from https://www.socialnisluzby. eu/images/obr/1617960742_srpen-zari.final.pdf

19. Mátel, A. (2019). Teorie sociální práce I [Theory of Social Work I] ( $1^{\text {st }}$ ed.). Prague: Grada. (In Czech).

20. Matoušek, O. (2011). Sociálni služby: Legislativa, ekonomika, plánování, hodnocení [Social services: legislation, economics, planning, evaluation] (2 $2^{\text {nd }}$ ed.). Praha: Portál. (In Czech).

21. Matoušek, O. (2012). Základy sociální práce ( $3^{\text {rd }}$ ed.). Praha: Portál. (In Czech). 
22. Matoušek, O. (2013). Metody a rízení sociální práce [Methods and management of social work] ( $3^{\text {rd }}$ ed.). Prague: Portal. (In Czech).

23. Megheirkouni, M. (2018). Leadership and management development post-war: exploring future trends. International Journal of Organizational Analysis, 26(1), 107-128. https://doi.org/10.1108/ IJOA-06-2017-1176

24. Mikova, I., Komarkova, L., \& Pudil, P. (2019). Support of development of nonprofit organizations through special training programs for their managers. International Scientific Conference "Contemporary Issues in Business, Management and Education", International Scientific Conference "Contemporary Issues in Business, Management and Economics Engineering". https://doi.org/10.3846/ cibmee. 2019.048

25. Mikuláštík, M. (2015). Manažerská psychologie ( $3^{\text {rd }}$ ed.). Praha: Grada. (In Czech).
26. Provazník, V., Bedrnová, E., Benák, R., \& Franková, E. (2012). Psychologie pro ekonomy a manažery [Psychology for economists and managers] ( $3^{\text {rd }} \mathrm{ed}$.). Prague: Grada. (In Czech).

27. Schneiderová, A. (2010). Kompetence manažerů $v$ sociálních službách [Competence of managers in social services] ( $1^{\text {st }}$ ed.). Ostrava: Repronis s.r.o. (In Czech).

28. Šedivý, M., \& Medlíková, O. (2017). Úspěšná nezisková organizace [Successful nonprofit organization] ( $3^{\text {rd }}$ ed.). Prague: Grada. (In Czech)

29. Špalek, J., Hyánek, V., \& Fónadová, L. (2017). Na penězích záleží: České neziskové organizace v 21. století [Money matters: Czech non-profit organizations in the 21st century] ( $1^{\text {st }}$ ed.). Brno: Masaryk University. (In Czech)

30. Tafvelin, S., Issaksson, K., \& Westerberg, K. (2018). The first year of service: A longitudinal study of organisational antecedents of transformational leadership in the social service organisations. British Journal of Social Work, 48(2), 430-448. https://doi.org/10.1093/ bjsw/bcx08

31. Tham, P., \& Strömberg, A. (2020). The Iron Cage of Leadership - the Role of First-Line Managers in Child Welfare. British Journal of Social Work, 50(2), 369388. https://doi.org/10.1093/bjsw/ bcz156

32. Vojtíšek, P. (2018). Princip solidarity ve financování služeb sociální péče [Principle of solidarity in the financing of social care services] ( $1^{\text {st }}$ ed.). Prague: Karolinum. (In Czech).

33. Zhang, H., Liu, Z., \& Wang, Y. (2020). How transformational leadership positively impacted organizational citizenship behavior in successful Chinese social work service organizations. Nonprofit Management and Leadership, 30(3), 467-485. https://doi. org/10.1002/nml.21391 